\title{
Konsep Pendidikan Modern dalam Perspektif Al-Qur'an
}

\author{
Heru Suparman \\ Pascasarjana Universitas Indraprasta PGRI Jakarta, Indonesia \\ pahe165@yahoo.co.id
}

\begin{abstract}
Abstrak:
Penemuan riset menyatakan bahwa pandangan atau tinjauan Alquran tentang Pendidikan Modern pada dasarnya sudah sesuai dengan ajaran Islam, khususnya Alquran yang menjadi sumber hukum Islam. Penemuan menarik lainnya pada riset tentang pendidikan Modern meliputi kritik Alquran terhadap pendidikan modern, tujuan pendidikan Islam, dan penanggung jawab pendidikan Islam. Dari beberapa karakteristik tersebut, diformulasikan dengan ayat-ayat Alquran dan tafsir sebagai dalil, bahwa konsep pendidikan modern ternyata selaras dengan ajaran-ajaran Islam dalam mengatur tatanan hidup manusia di muka bumi ini, terutama sekali dalam konteks pendidikan. Penulis dapat menyimpulkan bahwa Pendidikan Modern adalah cara-cara belajar yang sesuai dengan tuntutan era kekinian, untuk dapat dipersiapkan anak didik pada masanya.
\end{abstract}

Kata Kunci: Konsep Pendidikan, Pendidikan Modern, Perspektif Al-Qur'an

\begin{abstract}
:
Abstract. The research findings state that the views or reviews of the Koran regarding Modern Education are basically in accordance with Islamic teachings, especially the Koran which is the source of Islamic law. Other interesting findings in research on Modern education include the Qur'anic criticism of modern education, the goals of Islamic education, and the person in charge of Islamic education. From some of these characteristics, formulated with verses of the Koran and interpretations as an argument, that the concept of modern education is in harmony with the teachings of Islam in regulating the order of human life on this earth, especially in the context of education. The author can conclude that Modern Education is ways of learning in accordance with the demands of the present era, to be prepared by students in their time.
\end{abstract}

Keywords: Educational Concepts, Modern Education, Qur'anic Perspective 
Heru Suparman

\section{Pendahuluan}

Pendidikan memiliki peran penting dalam kehidupan manusia. Salah satunya sebagai media yang berfungsi menjadikan manusia lebih baik dari sebelumnya. Peran penting lainnya adalah untuk memanusiakan manusia. Akan tetapi, pada kenyataan sebagian orang hanya memahami secara garis besar hal-hal yang berhubungan dengan pendidikan. Beberapa hanya mengetahui pendidikan sebagai sarana belajar, terutama sarana belajar dalam bidang akademis. Sehingga pengertian pendidikan secara mendasar kurang dipahami.

Secara etimologi, pendidikan berasal dari kata didik, artinya bina mendapat awalan pen-, akhiran -an, yang maknanya sifat dari perbuatan membina atau melatih. ${ }^{1}$ Oleh karena itu, pendidikan merupakan pembinaan, pelatihan, pengajaran dan semua hal yang merupakan bagian dari usaha manusia untuk meningkatkan kecerdasan dan keterampilannya. ${ }^{2}$ Pendidikan diterjemahkan dari Bahasa Arab "Tarbiyah" dengan kata kerjanya "Robba" yang berarti mengasuh, mendidik, memelihara. ${ }^{3}$ Sementara Ngalim Purwanto mengemukakan pendidikan adalah segala usaha orang dewasa dalam pergaulan dengan anak-anak untuk memimpin perkembangan jasmani dan rohaninya kearah kedewasaan. ${ }^{4}$ Secara formal pendidikan di Indonesia diatur dalam Undang-Undang Sistem Pendidikan Nasional (Sisdiknas) Bab I pasal 1 ayat 1, pendidikan adalah usaha sadar dan terencana untuk mewujudkan suasana belajar dan proses pembelajaran agar peserta didik secara aktif mengembangkan potensi dirinya untuk memiliki kekuatan spiritual keagamaan, pengendalian diri, serta keterampilan yang diperlukan dirinya, masyarakat, bangsa dan negara. ${ }^{5}$

Sedangkan secara terminologi, pendidikan dapat diartikan sebagai pembinaan, pembentukan, pengarahan, pencerdasan dan pelatihan yang ditujukan kepada semua anak didik secara formal maupun nonformal dalam rangka menuju pendewasaan. Dengan kata lain pendidikan adalah segala aktifitas atau upaya sadar dan terencana yang dirancang untuk membantu seseorang mengembangkan pandangan hidup, sikap hidup dan keterampilan hidup.

Kaum pragmatik dengan tokohnya seperti John Dewey, cenderung mendefinisikan pendidikan dalam arti luas dan mengecam praktek pendidikan di sekolah yang diselenggarakan pada zamannya. Pada umumnya, mereka mengecam praktek pendidikan di sekolah karena di

\footnotetext{
${ }^{1}$ Kamus Besar Bahasa Indonesia, Jakarta: Gitamedia Press, 2015, hal. 596.

${ }^{2}$ Hasan Basri, Filsafat Pendidikan Islam, Bandung: Pustaka Setia, 2009, hal. 53.

${ }^{3}$ Zakiyah Darajat, Pendidikan Islam Dalam Keluarga dan Sekola, Jakarta: Ruhama, 1996, hal. 25.

${ }^{4}$ M. Ngalim Purwanto, Administrasi dan Supervisi Pendidikan. Bandung: Remaja Rosdakarya, 1995, hal. 11.

${ }^{5}$ Undang-Undang Sistem Pendidikan Nasional No. 20, 2003.
} 
sekolah berlangsung praktek dehumanisasi, yaitu proses pengikisan martabat kemanusiaan. Sekolah terasing dari kehidupan nyata. Pola hubungan guru dan murid adalah otoriter. sehinggga, kurang berlangsung perkembangan individu secara optimal.

Kaum behavioris dengan para tokoh-tokohnya, seperti B.F Skinner, B. Watson, dan sebagainya, cenderung mendefinisikan pendidikan dalam arti sempit. Sekurang-kurangnya, mereka mempunyai pandangan yang optimis terhadap peranan sekolah dalam menyelenggarakan pendidikan, dan pesimis atau meragukan peranan pendidikan dalam bentuk-bentuk pengalaman belajar dalam hidup yang tidak dilembagakan.

Mereka mempunyai keyakinan yang sangat kuat tentang masa depan sekolah sebagai hal ihwal yang berkenaan dengan rekayasa pengubahan tingkah laku sekolah hendaknya dirancang seperti halnya para insinyur yang bekerja merancang sebuah mesin yang canggih. Sekolah sebagai lembaga berlangsungnya proses rekayasa perubahan tingkah laku harus didasarkan pada kurikulum yang dirancang secara ilmiah dan bentuk-bentuk kegiatannya harus diorganisasikan dengan penuh perhatian dan dilaksanakan dengan penuh disiplin. ${ }^{6}$

Optimisme kaum behavioris tentang sekolah antara lain dikemukakan oleh john. B. Watson, seorang peletak dasar ajaran behavioris modern, sebagai berikut:

"Berilah saya selusin anak yang sehat, kondisi badannya baik, dan dunia pribadiku yang terarah kepada upaya mendidik mereka dan saya akan jamin untuk memilih anak yang manapun melihatnya menjadi seorang spesialis apapun yang akan saya pilih, apakah dokter, ahli hukum, seniman, saudagar dan bahkan menjadi pengemis dan pencuri, tak peduli bakatnya, minatnya, kecenderungannya, kemampuannya, pekerjaan dan keturunan rasnya. "7

Pernyataan di atas mengandung makna bahwa, pengaruh lingkungan dalam bentuk latihan atau pengajaran terhadap pembentukan kemampuan- kemampuan seseorang sangat menentukan, dan dengan demikian mengajarkan paham determinisme lingkungan. B.F Skinner, salah seorang pakar behaviorisme terkemuka, meletakkan dasar pada determinisme lingkungan dalam teori pendidikan.

Skiner dalam beyond Freedom and dignity antara lain menyatakan bahwa: "Pengaruhpengaruh lingkungan membentuk kita seperti apa yang ada sekarang ini."8 Dia juga menyatakan bahwa kita dikontrol oleh lingkungan kita dan sebagian besar lingkungan

\footnotetext{
${ }^{6}$ Redja Mudyahardjo, Filsafat Ilmu Pendidikan, Suatu Pengantar,...hal. 45-48.

${ }^{7}$ Redja Mudyahardjo, Filsafat Ilmu Pendidikan, Suatu Pengantar,...hal. 43-49.

${ }^{8}$ Redja Mudyahardjo, Filsafat Ilmu Pendidikan, Suatu Pengantar,...hal. 47.
} 
membantu kita seperti apa yang dapat kita capai sekarang ini. Meskipun demikian, kita dapat selalu mempengaruhi lingkungan kita. Kita sekaligus dikontrol dan mengontrol. Pada akhirnya kita mencapai keadaan yang lebih baik apabila kita memahami hal tersebut dan perlaku kita aktif mengikutinya.

Sejalan dengan itu, maka pendidikan mengalami perubahan (inovasi), sebab proses pendidikan yang tidak sesuai dengan tuntutan perkembangan zaman hanya akan membuat manusia stagnan (jumud). Oleh karena itu, pemahaman atau pandangan orang mengenai hakikat pendidikan itupun berubah-ubah, yang secara sederhana dapat dikategorikan sebagai pandangan pendidikan tradisional dan pendidikan modern.

Ahli pendidikan modern mendifinisikan, sebagaiman dikatakan P.J.Hills bahwa: Education has most scienties two principle roles, that of passing on knowledge from one generation to the next, and that providing people with skill that enable to analyse, diagnos and thus question. "Pendidikan dalam masyarakat pada umumnya memiliki dua peran pokok yaitu menyampaikan pengetahuan kepada generasi ke generasi berikutnya dan memberikan bekal kepada manusia dengan keahlian yang dapat untuk menganalisa, mendiagnosa, dan juga kemampuan bertanya".

Dengan demikian penulis dapat menyimpulkan bahwa Pendidikan Modern adalah cara-cara belajar yang sesuai dengan tuntutan era kekinian, untuk dapat dipersiapkan anak didik pada masanya. Berkaitan dengan pengertian pendidikan modern, dikaitkan dengan tujuan pendidikan. Pendidikan modern berlaku bagi hidup untuk menumbuhkan, memupuk, mengembangkan, memelihara dan mempertahankan tujuan pendidikan yang telah dicapai.

\section{Dasar Pendidikan Islam}

Dasar atau landasan pendidikan Islam tidak dapat dipisahkan dari sumber ajaran Islam itu sendiri, yakni Alquran dan Al-Hadits. Zakiyah Daradjat mengatakan bahwa, landasan itu terdiri dari Alquran dan Haids Nabi Muhammad yang dapat dikembangkan dengan Ijtihad almaslaha al- mursalah, istihsan, qiyas dan sebagainya. ${ }^{9}$ Menurut Nur Uhbiyati, dasar pendidikan Islam secara garis besar ada 3 yaitu; Alquran, Haids, dan Perundang-undangan yang berlaku di negara kita. ${ }^{10}$

${ }^{9}$ Zakiyah Darajat, Pendidikan Islam Keluarga dan Sekolah, Jakarta: Ruhana, 1992, hal. 19.

${ }^{10}$ Nur Uhbiyati, Ilmu Pendidikan Islam, Bandung: Pustaka Setia, 1998, hal. 9. 


\section{Dasar Pendidikan Islam dalam Alquran}

Al-Qur'an diturunkan Allah SWT dalam bahasa Arab Quraisy sesuai dengan dialek-dialek bangsa Arab sebagai bahasa yang paling fasih. Hal ini ditegaskan dalam Al-Qur'an surat Ash- Shu'ara/26: 192-195 sebagai berikut,

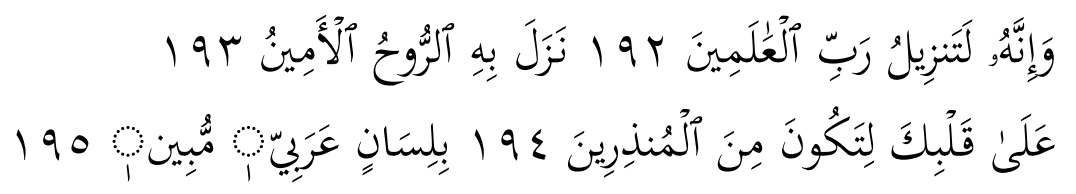

Dan sesungguhnya al-Qur'an itu benar-benar diturunkan oleh Allah semesta alam, dia dibawa turun oleh Ruh Al-Amin ke dalam hatimu (Muhammad) agar kamu menjadi salah seorang yang memberi peringatan, dengan bahasa Arab yang jelas.

Ayat tersebut memberi pengertian bahwa Alquran diturunkan Allah dalam bahasa Arab, teristimewa di dalamnya bahasa Arab Quraisy. Bangsa Arab yang hidup pada masa awal turunnya Al-Qur'an, memahami lafazh-lafazh Al-Qur'an dan susunan-susunannya sesuai dengan kemampuan mereka tentang hal itu.

Meskipun bangsa Arab paham terhadap Al-Qur'an, karena diturunkan dengan bahasa mereka sendiri, tetapi tingkat pemahaman mereka berbeda-beda sejalan dengan berbedanya kecerdasan, lama bergaul dengan Rasulullah ditambah dengan kesungguhan atau tidaknya mereka dalam memahami Al-Qur'an. Meskipun demikian, secara umum dapat dikemukakan di sini bahwa pada masa Rasulullah SAW. masih hidup tidak ada kesulitan berarti yang dialami oleh para sahabat.

Alquran merupakan firman Allah yang disampaikan melalui malaikat Jibril kepada Nabi Muhammad, yang di dalamnya terkandung ajaran pokok yang di lembagakan untuk seluruh aktivitas hidup dan kehidupan. Alquran merupakan sumber hukum yang pertama, sedangkan yang dimaksud dengan Al-Hadits ialah perkataan, perbuatan dan ketetapan Rasulullah juga sebagai sumber hukum yang kedua.

Alquran sebagai sumber ajaran Islam, berisi petunjuk bagi manusia menuju ke arah jalan yang diridoi Allah. Maka Alquran telah mencakup berbagai masalah baik yang menyangkut ibadah ritual atau ibadah sosial yang berisi kemasyarakatan, termasuk ini di dalamnya tentang pendidikan banyak mendapat tuntunan yang jelas di dalam Alquran. Sebagaimana firman Allah dalam surat Al-Shad/38: 29 yang berbunyi:

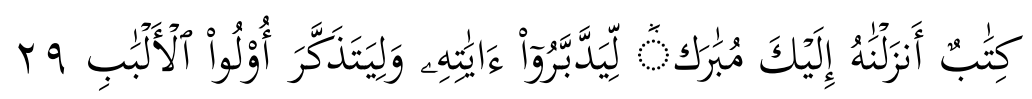


Heru Suparman

Ini adalah sebuah kitab yang kami turunkan kepadamu penuh dengan berkah supaya mereka memperhatikan ayat-ayatnya dan supaya mendapat pelajaran orang-orang yang mempunyai pikiran.

Jadi orang Islam meletakkan Alquran dan Hadits menjadi dasar ilmu pendidikan Islam, karena kedua sumber tersebut dijamin kebenarannya.

\section{Dasar Pendidikan Islam dalam Hadis}

Rasullah saw. mengatakan bahwa beliau adalah guru didik. Dalam kaitan dengan ini $\mathrm{M}$. Athiyah al-Abrasyi ${ }^{11}$ mengatakan; Pada suatu hari Rasul keluar dari rumahnya dan beliau menyaksikan adanya dua pertemuan; dalam pertemuan pertama, orang-orang yang berdoa kepada Allah 'Azza wajalla, mendekati diri kepada-Nya; dalam pertemuan kedua orang sedang memberikan pelajaran. Langsung beliau bersabda:

"Mereka ini (pertemuan pertama), minta kepada Allah, bila Tuhan menghendaki maka Ia akan memenuhi permintaan tersebut, dan jika Ia tidak menghendaki maka tidak akan dikabulinya. Tetapi golongan kedua ini, mereka mengajar manusia, sedangkan saya sendiri diutus untuk juru didik”.

Selain itu beliau duduk pada pertemuan kedua ini. Praktik ini membuktikan kepada kita suatu contoh terbaik betapa Rasul mendorong orang belajar dan menyebarkan ilmu secara luas dan suatu pujian atas keutamaan juru didik. Di samping itu sebagaimana Rasullah sendiri kepada orang kafir- kafir yang tertawan akibat perang Badar, apabila ia ingin bebas supaya terlebih dahulu mereka mau mengajarkan 10 orang Islam.

Sikap Rasul seperti tersebut di atas merupakan fakta bahwa Islam sangat mementingkan adanya pendidikan dan pengajaran. Rasullah SAW. bersabda:

"Barang siapa yang menyembunyikan ilmunya maka Tuhan akan mengekangnya dengan kekang berapi” (HR. Ibnu Majah).

Masih banyak hadis Rasul yang menjelaskan tentang pendidikan dan pengajaran di antaranya sebagai berikut, Rasulullah bersabda:

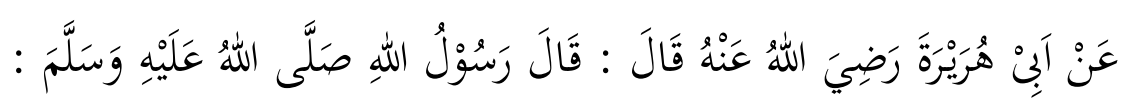

\footnotetext{
${ }^{11}$ Al-Athiyah al-Abrasy, Muhammad, Al-Tarbiyah al-Islamiyah WaFalsafatuha. Qahirah: Isa al-Babi al-Halaby, 1969. hal. 36-37.
} 


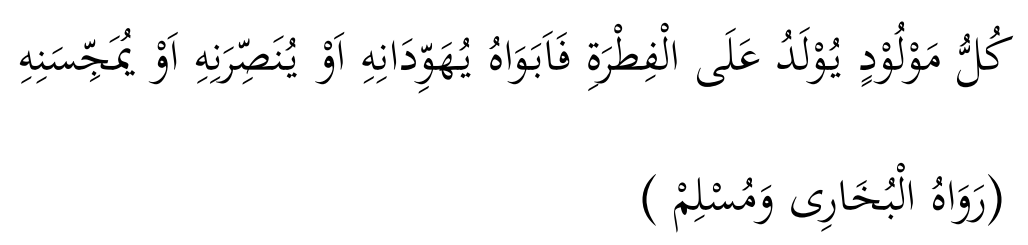

Dari Abu Hurairah R.A, Ia berkata: Rasulullah SAW bersabda : "Setiap anak dilahirkan dalam keadaan suci, ayah dan ibunyalah yang menjadikan Yahudi, Nasrani, atau Majusi." (HR. Bukhari dan Muslim) ${ }^{12}$

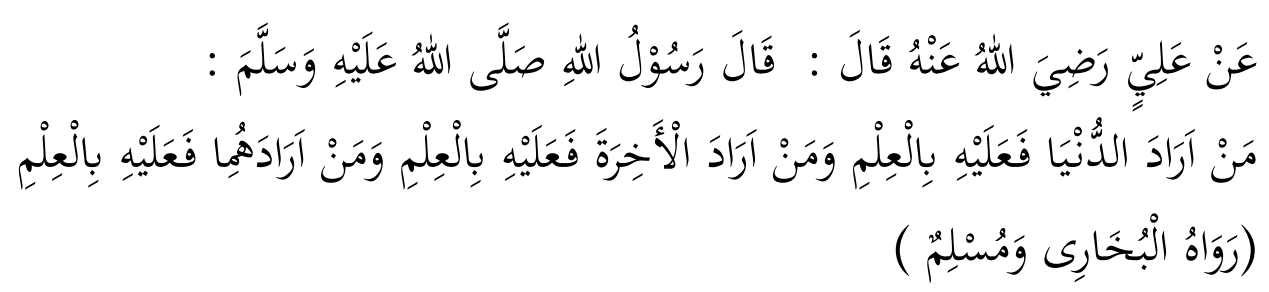

"Barangsiapa yang menghendaki kebaikan di dunia maka dengan ilmu. Barangsiapa yang menghendaki kebaikan di akhirat maka dengan ilmu. Barangsiapa yang menghendaki keduanya maka dengan ilmu" (HR. Bukhari dan Muslim) $)^{13}$

Dari penjelasan hadits tersebut di atas dapat disimpulkan bahwa Rasullah menjunjung tinggi pendidikan dan memotivasi agar berkiprah pada dunia pendidikan dan pengajaran dan mewajibkan kepada umatnya untuk menyelenggarakan pendidikan dan pengajaran.

\section{Dasar Pendidikan Islam dalam UUD 1945}

Pasal 29 ayat 1 berbunyi: "Negara berdasarkan atas ketuhanan Yang Maha Esa". Ayat 2 berbunyi: "Negara menjamin kemerdekaan tiap-tiap penduduk untuk memeluk agamanya masing-masing dan beribadat menurut agamanya dan kepercayaannya itu."

Pasal 31 ayat 1 berbunyi: "Tiap-tiap warga negara berhak mendapat pengajaran." Ayat 2 berbunyi: "Pemerintah mengusahakan dan menyelenggarakan satu sistem pengajaran nasional, yang diatur dengan undang-undang.

Pada pasal 29 dan 31 UUD 1945 ini memberikan jaminan kepada warga negara Republik Indonesia untuk memeluk agama dan beribadat sesuai dengan agama yang dipeluknya bahkan mengadakan kegiatan yang dapat menunjang bagi pelaksanaan ibadat dan memberikan hak

12 Thoha 'Aasyur, 301 Hadits Pilihan, Jakarta : Pustaka Amani, 1969, hal. 123.

13 Thoha 'Aasyur, 301 Hadits Pilihan, hal. 126. 
Heru Suparman

atas pendidikan/pengajaran. Dengan demikian pendidikan Islam yang searah dengan bentuk ibadat yang diyakininya diizinkan dan dijamin oleh negara.

\section{Dasar Pendidikan Islam dalam GBHN}

Dalam GBHN Tahun 1993 Bidang Agama dan Kepercayaan Terhadap Tuhan Yang Maha Esa No. 23 disebutkan: "Kehidupan beragama dan kepercayaan terhadap Tuhan Yang Esa makin dikembangkan sehingga terbina kualitas keimanan dan ketakwaan terhadap Tuhan Yang Maha Esa, kualitas kerukunan antar dan antara umat beragama dan penganut kepercayaan terhadap Tuhan Yang Maha Esa dalam usaha memperkokoh persatuan dan kesatuan bangsa serta meningkatkan amal untuk bersama-sama membangun masyarakat”.

Memperhatikan GBHN tahun 1993 tersebut di atas dapat disimpulkan bahwa kehidupan kedamaian termasuk (di dalamnya agama Islam), supaya semakin dikembangkan dalam kehidupan masyarakat. Sedangkan untuk mengembangkan keagamaan itu sangat diperlukan pelaksanaan pendidikan termasuk di dalamnya pendidikan Islam yang tertera dalam UU No. 20 Tahun 2003 tentang Sistem Pendidikan Nasional

1. Pasal 5 ayat 1 disebutkan

"Seiap warga negara mempunyai hak yang sama untuk memperoleh pendidikan yang bermutu".

2. Pasal 10 disebutkan:

"Pemerintah dan pemerintah daerah berhak mengarahkan, membimbing, membantu, dan mengawasi penyelenggaraan pendidikan sesuai dengan peraturan perundang-undangan yang berlaku."

3. Pasal 11 ayat 1 disebutkan:

"Pemerintah dan pemerintah daerah wajib memberikan layanan dan kemudahan, serta menjamin terselenggaranya pendidikan yang bermutu bagi setiap warga negara tanpa diskriminasi."

4. Pasal 11 ayat 1 disebutkan:

"Setiap peserta didik pada setiap satuan pendidikan berhak:

a. Mendapatkan pendidikan agama sesuai dengan agama yang dianutnya dan diajarkan oleh pendidik yang seagama;

b. Mendapatkan pelayanan pendidikan sesuai dengan bakat, minat, dan kemampuannya; 
c. Mendapatkan beasiswa bagi yang berprestasi yang orang tuanya tidak mampu membiayai pendidikan;

d. Mendapatkan biaya pendidikan bagi mereka yang orang tuanya tidak mampu membiayai pendidikannya;

e. Pindah ke program pendidikan pada jalur dan satuan pendidikan lain yang setara;

f. Menyeselesaikan program pendidikan sesuai dengan kecepatan belajar masing-masing dan tidak menyimpang dari ketentuan batas waktu yang ditetapkan.

Sedangkan dari Undang-undang No.20 Tahun 2003 ini dapat disimpulkan bahwa pendidikan keagamaan bermaksud mempersiapkan peserta didik untuk dapat menjalankan peranannya sebagai pemeluk agama yang benar-benar memadai. Di antara syarat dan prasyarat agar peserta didik dapat menjalankan peranannya dengan baik diperlukan pengetahuan Ilmu Pendidikan Islam. Mengingat ilmu ini tidak hanya menekankan pada segi teoritis saja, tetapi juga praktis. Ilmu Pendidikan Islam termasuk ilmu praktis maka peserta didik diharapkan dapat menguasai ilmu tersebut secara penuh baik teoritis maupun praktis, sehingga ia benar-benar mampu memainkan peranannya dengan tepat dalam hidup dan kehidupan.

\section{Tujuan Pendidikan Islam}

Tujuan pendidikan Islam tidak terlepas dari tujuan hidup manusia dalam Islam, yaitu untuk menciptakan pribadi-pribadi hamba Allah yang selalu bertakwa kepada-Nya, dan dapat mencapai kehidupan yang berbahagia di dunia dan akhirat. Menurut Abdul Fatah Jalal dalam Ahmad Tafsir, tujuan umum pendidikan Islam ialah terwujudnya manusia sebagai hamba Allah. Jadi menurut Islam, pendidikan haruslah menjadikan seluruh manusia yang menghambakan kepada Allah. Menurut Ahmad Tafsir ${ }^{14}$ yang dimaksudkan menghambakan diri ialah beribadah kepada Allah. Islam menghendaki agar manusia dididik supaya ia mampu merealisasikan tujuan hidupnya sebagaimana yang telah digariskan oleh Allah. Adapun tujuan pendidikan Islam ini tidak jauh berbeda dengan yang dikemukakan para ahli. Menurut Ahmadi. ${ }^{15}$ Tujuan pendidikan Islam adalah sejalan dengan pendidikan hidup manusia dan peranannya sebagai makhluk Allah SWT yaitu semata-mata hanya beribadah kepada-Nya.

${ }^{14}$ Ahmad Tafsir, Ilmu Pendidikan dalam Perspektif Islam, Bandung: PT. Remaja Rosdakarya, 2001, hal. 16.

${ }^{15}$ Achmadi, Islam sebagai Paradigma Ilmu Pendidikan, Yogyakarta: Aditya Media,1992, hal. 63. 
Tujuan hidup manusia itu menurut Allah ialah beribadah kepada Allah. Seperti firman Allah dalam surat adh-Dhariyat/51: 56 yang berbunyi:

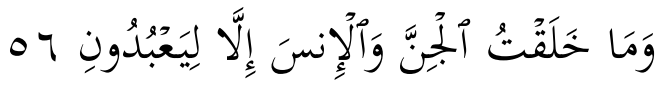

"Dan Aku tidak menciptakan jin dan manusia melainkan supaya mereka mengabdi kepada-Ku”.

Ibadah itu tidak terbatas pada menunaikan salat, puasa pada bulan Ramadhan, mengeluarkan zakat, ibadah haji, serta mengucapkan syahadat. Tetapi sebenarnya ibadah itu mencakup semua amal, pikiran, dan perasaan yang dihadapkan (atau disadarkan) kepada Allah. Aspek ibadah merupakan kewajiban orang Islam untuk mempelajarinya agar ia dapat mengamalkannya dengan cara yang benar. Ibadah ialah jalan hidup yang mencakup seluruh aspek kehidupan serta segala yang dilakukan manusia berupa perkataan, perbuatan, perasaan, pemikiran yang disangkutkan dengan Allah. Hal ini telah ditegaskan dalam surat ali- Imran/3: 102, sebagai berikut,

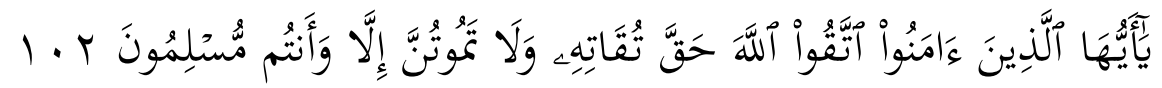

"Hai orang-orang yang beriman, bertakwalah kepada Allah sebenar-benar takwa kepada-Nya; dan janganlah sekali-kali kamu mati melainkan dalam Keadaan beragama Islam."

Dalam konteks sosiologi pribadi yang bertakwa menjadi rahmatan lil'alamin, baik dalam skala kecil maupun besar. Tujuan hidup manusia dalam Islam inilah yang dapat disebut juga sebagai tujuan akhir pendidikan Islam. Tujuan khusus yang lebih spesifik menjelaskan apa yang ingin dicapai melalui pendidikan Islam. Sifatnya lebih praktis, sehingga konsep pendidikan Islam jadinya tidak sekedar idealisasi ajaran-ajaran Islam dalam bidang pendidikan. Dengan kerangka tujuan ini dirumuskan harapan-harapan yang ingin dicapai di dalam tahap-tahap tertentu proses pendidikan, sekaligus dapat pula dinilai hasil-hasil yang telah dicapai.

Hampir semua cendekiawan muslim sepakat, bahwa tujuan pendidikan Islam adalah pembentukan pribadi muslim yang sempurna sebagai hamba sekaligus khalifah Allah di muka bumi. Kesempurnaan pribadi muslim itu nantinya dapat ditunjukkan dengan keimanan yang 
kuat dan ketakwaan serta perbuatan baik, atau yang lebih dikenal dengan sebutan amal saleh.

Pendidikan Islam harus mampu menciptakan manusia muslim yang berilmu tinggi, dimana iman dan takwanya menjadi pengendali dalam penerapan atau pengamalannya dalam masyarakat manusia. ${ }^{16}$

Pada pengertian yang lain dapat dikatakan bahwa pendidikan Islam itu bertujuan untuk membentuk kepribadian Muslim. Marimba ${ }^{17}$ menggolongkan kepribadian menjadi tiga aspek:

a. Aspek-aspek kejasmanian; meliputi tingkah laku luar yang mudah tampak dan dapat diketahui dari luar. Misalnya cara-cara berbuat, cara-cara berbicara dan sebagainya.

b. Aspek-aspek kejiwaan; meliputi aspek-aspek yang tidak segera dapat dilihat dan diketahui dari luar, misalnya: cara-cara berpikir, sikap dan minat.

c. Aspek-aspek kerohanian yang luhur; meliputi aspek-aspek kejiwaan yang lebih abstrak yaitu filsafat hidup dan kepercayaan. Ini meliputi sistem nilai-nilai yang telah meresap di dalam kepribadian itu, yang telah menjadi bagian dan mendarah daging dalam kepribadian itu yang mengarahkan dan memberi corak seluruh kehidupan individu itu. Bagi orang-orang yang beragama, aspek inilah yang menuntutnya ke arah kebahagiaan, bukan saja di dunia tetapi juga di akhirat. Aspek inilah yang memberi kualitas kepribadian keseluruhannya.

Marimba mengambil kesimpulan kepribadian Muslim ialah kepribadian yang seluruh aspekaspeknya yakni baik tingkah laku luarnya, kegiatan-kegiatan jiwanya, maupun filsafat hidup dan kepercayaan menunjukkan pengabdian diri kepada Tuhan penyerahan diri kepada-Nya.

Adapun prinsip ajaran moral yang harus menjadi hiasan tiap pribadi muslim menurut Alquran sebagai berikut:

a. Seorang muslim tidak boleh memandang hina kepada orang lain. (al- Hujurat: 13).

b. Seorang muslim tidak boleh buruk sangka dan tidak boleh pula mengintaiintai kesalahan orang lain. (al-Hujurat: 12).

c. Islam menyuruh pada persatuan. (ali- Imran: 103, al-Anfal: 46)

${ }^{16}$ Muzayyin Arifin, Filsafat Pendidikan Isla, Jakarta: Bumi Aksara. 2005, hal. 112.

${ }^{17}$ Ahmad D.Marimba, Pengantar Filsafat Pendidikan Islam,...hal. 67. 
d. Islam melarang takabur dan sombong. (al-Isra': 37, Luqman: 18) yang emosional. Perasaan mempengaruhi tingkah lakunya. Gejala-gejalanya tampak dalam gambaran bentuk; gerakan dan diamnya; makan dan minumnya serta diam atau geraknya.

e. Islam melarang seorang mukmin mencari aib orang lain. (al-Isra': 36).

f. Islam menyuruh berlaku adil dan membenci penganiayaan. (al-Nahl:

90, al-An'am: 152, al-Maidah: 8).

g. Islam memperteguh tali silaturahmi, (al-Isra': 26, al-Nisa':1).

h. Islam mewasiatkan agar orang baik dengan tetangganya. (al-Nisa':36).

\section{i. Islam menyeru agar orang tolong-menolong dan mementingkan orang}

lain. (al-Maidah: 2, al-Baqarah: 280, ali- Imran: 92, al- Hasyr: 9). ${ }^{18}$

Demikianlah ajaran Alquran tentang tingkah laku dan budi pekerti seorang muslim. Ajaranajaran tersebut sudah tentu harus ditanamkan, diajarkan didikan kepada setiap individu muslim agar dapat menjadi hiasan dirinya. Hasil usaha tersebut akan membekas pada tiap pribadi muslim yaitu berupa sifat-sifat yang diwajibkan oleh Islam dimiliki oleh setiap muslim.

Berkenaan dengan tujuan pendidikan, ditegaskan bahwa tujuan pendidikan Islam adalah pembentukan manusia yang bertindak sebagai khalifah yang ciri-cirinya terkandung dalam konsep ibadah dan amanah. ${ }^{19}$ Jadi, tujuan-tujuan pendidikan jika mengikuti definisi ini adalah perubahan-perubahan yang diinginkan pada tiga bidang asasi, yaitu:

1. Tujuan Individual yang berkaitan dengan individu- individu, pelajaran yang berbuat dengan pribadi-pribadi mereka, dan apa yang berkaitan dengan individuindividu tersebut. Perubahan yang diinginkan terletak pada tingkah laku aktivitas dan pencapaiannya, pertumbuhan yang diinginkan pada pribadi mereka, dan persiapan yang dimestikan kepada mereka pada kehidupan dunia dan akhirat.

2. Tujuan Sosial yang berkaitan dengan kehidupan masyarakat secara keseluruhan, dengan tingkah laku masyarakat umumnya dan dengan apa yang berkaitan dengan kehidupan ini mengenai perubahan yang diinginkan, pertumbuhan, kekayaan pengalaman, dan kemajuan yang diinginkan.

3. Tujuan Profesional yang berkaitan dengan pendidikan dan pengajaran sebagai ilmu, sebagai seni, sebagai profesi, dan sebagai suatu aktivitas di antara aktivitas-aktivitas masyarakat.

\footnotetext{
${ }^{18}$ Zuhairini, dkk, Filsafat Pendidikan Islam, Jakarta: Bumi Aksara, 1991, hal. 202.

${ }^{19}$ Hasan Langgulung, Beberapa Pemikiran tentang Pendidikan,...hal. 46.
} 
Hal ini senada dan sejalan dengan tujuan pendidikan nasional Indonesia yang berdasarkan Pancasila dan UUD 1945 yaitu:

Mencerdaskan kehidupan bangsa dan mengembangkan manusia Indonesia seutuhnya, yaitu manusia yang beriman dan bertakwa kepada Tuhan Yang Maha Esa dan berbudi pekerti luhur, memiliki pengetahuan dan keterampilan, kesehatan jasmani dan rohani, kepribadian yang mantap dan mandiri serta bertanggung jawab kemasyarakatan dan kebangsaan (UU No.2 Tahun 1989, 1992:4).

Ahmad D. Marimba mengemukakan dalam buku Nur Uhbiyati, bahwa ada dua macam tujuan yaitu tujuan sementara dan tujuan akhir.

\section{Tujuan Sementara}

Yaitu sasaran sementara yang harus dicapai oleh umat Islam yang melaksanakan pendidikan Islam. Tujuan sementara di sini yaitu tercapainya berbagai kemampuan seperti kecakapan jasmaniah, pengetahuan membaca, menulis, pengetahuan ilmu-ilmu kemasyarakatan, kesusilaan, keagamaan, kedewasaan jasmani-rohani dan sebagainya.

Kedewasaan rohaniah tercapai apabila orang telah mencapai kedewasaan jasmaniah. Di dalam Islam disebutkan bahwa seseorang telah mencapai jasmaniah apabila ia telah balig dengan ciriciri sebagai berikut:

1. Laki-laki berumur 15 tahun, perempuan berumur 9 tahun

2. Bermimpi

3. Mengeluarkan haid bagi perempuan

Sedangkan kedewasaan rohaniah, bukanlah merupakan sesuatu yang statis, melainkan merupakan sesuatu proses. Oleh karena itu sangat sukarlah ditentukan kapan seseorang yang telah mencapai dewasa rohaniah dalam arti kata yang sesungguh- sungguhnya. Ukuranukuran mengenai hal ini pun bersifat teoritis dan juga merupakan ukuran gradual saja (lebih atau kurang). Seseorang dinyatakan telah mencapai dewasa rohaniah apabila ia telah dapat memilih sendiri, memutuskan sendiri dan bertanggung jawab sendiri sesuai dengan nilainilai yang dianutnya. Dengan demikian maka mencapai kedewasaan ini hanya merupakan tujuan sementara untuk menuju kepada tujuan akhir. 
Heru Suparman

\section{Tujuan Akhir}

Sementara tujuan akhir pendidikan Islam yaitu terwujudnya kepribadian muslim. Sedangkan kepribadian muslim adalah kepribadian yang seluruh aspek-aspeknya merealisasikan atau mencerminkan ajaran Islam. ${ }^{20}$

Menurut Ahamad D. Marimba, aspek-aspek kepribadian itu dapat dikelompok ke dalam 3 hal, yaitu:

1. Aspek-aspek jasmaniah; meliputi tingkah laku luar yang mudah tampak dan ketahuan dari luar, misalnya; cara-cara berbuat, cara-cara berbicara dan sebagainya.

2. Aspek-aspek kejiwaan, meliputi aspek-aspek yang tidak segera dapat dilihat dan ketahanan dari luar, misalnya cara-cara berpikir, sikap (berupa pendirian atau pandangan seseorang dalam menghadapi seseorang atau sesuatu hal) dan umat.

3. Aspek-aspek kerohanian yang benar; meliputi aspek-aspek kejiwaan yang lebih abstrak yaitu filsafat hidup dan kepercayaan. Isi meliputi sistem nilai-nilai yang telah meresap di dalam kepribadian itu, yang telah menjadi bagian dan mendarah daging dalam kepribadian individu itu. Bagi orang yang beragama, aspek-aspek inilah yang menuntutnya ke arah kebahagiaan, bukan saja di dunia tetapi juga di akhirat. Aspekaspek inilah memberi kualitas kepribadian keseluruhannya. ${ }^{21}$

Tujuan yang dimaksud di sini adalah agar manusia mempunyai pengetahuan sehingga dapat beribadah dan berujud serta mendekatkan diri kepada-Nya. Itu berarti bahwa tujuan pendidikan adalah untuk mendapatkan rida-Nya. Masalah ini terlihat jelas dalam surat al-Alaq ayat $1-5$.

Telah diungkapkan pada bagian awal bahwa perintah membaca pada ayat pertama surat alAlaq langsung diikuti dengan menyebutkan nama Allah. Semata-mata karena mengharap rida Allah SWT. Semua pekerjaan yang dimulai dengan niat ikhlas dan hanya mengharap rida Allah semata-mata merupakan ibadah yang tak ternilai harganya. Jika demikian, tujuan pendidikan yang dicanangkan dalam surat dan ayat tersebut adalah beribadah semata-semata karena Allah SWT. Karena itu, sikap ikhlas sangat dituntut aplikasinya dari semua yang terlibat dalam proses pendidikan tersebut.

${ }^{20}$ Nur Uhbiyati, Ilmu Pendidikan Islam,...hal. 9.

${ }^{21}$ Ahmad D. Marimba, Pengantar Filsafat Pendidikan Islam,...hal. 45-46 
Dari pembahasan tentang tujuan pendidikan Islam di atas sebetulnya dapat dikatakan bahwa sesungguhnya tujuan dari pendidikan Islam itu adalah tercapainya tujuan dari agama Islam itu sendiri. Dengan demikian untuk mencapai tujuan pendidikan Islam, pelaksanaannya harus berpegang teguh pada prinsip- prinsip pendidikan yang bersumber dari nilai-nilai Alquran dan Haids. Dalam hal ini, paling tidak ada lima prinsip dalam pendidikan Islam. ${ }^{22}$ Kelima prinsip tersebut adalah:

Pertama, prinsip integrasi (tauhid). Prinsip ini memandang adanya wujud kesatuan dunia dan akhirat. Oleh karena itu, pendidikan akan meletakkan posisi yang seimbang untuk mencapai kebahagiaan di dunia sekaligus di akhirat.

Kedua, prinsip keseimbangan. Prinsip ini merupakan konsekuensi dari prinsip integrasi. Keseimbangan yang proporsional antara muatan ruhaniah dan jasmaniah, antara ilmu murni dan ilmu terapan, antara teori dan praktik, dan antara nilai yang menyangkut akidah, syariah dan akhlak

Ketiga, prinsip persamaan dan pembebasan. Prinsip ini dikembangkan dari nilai tauhid, bahwa Tuhan adalah Esa. Oleh karena itu, setiap individu dan bahkan semua makhluk hidup diciptakan oleh pencipta yang sama (Tuhan). Perbedaan hanyalah unsur untuk memperkuat persatuan. Pendidikan Islam adalah suatu upaya untuk membebaskan manusia dari belenggu nafsu dunia menuju pada nilai tauhid yang bersih dan mulia. Manusia dengan pendidikan, diharapkan bisa terbebas dari belenggu kebodohan, kemiskinan, kejumudan dan nafsu kebinatangannya.

Keempat, prinsip kontinuitas dan berkelanjutan (istiqomah). Dari prinsip inilah dikenal konsep pendidikan seumur hidup (long life education). Di dalam Islam, belajar adalah satu kewajiban yang tidak pernah dan tidak boleh berakhir. Seruan membaca yang ada dalam Alquran merupakan perintah yang tidak mengenal batas waktu. Dengan menuntut ilmu secara terus menerus, diharapkan akan muncul kesadaran pada diri manusia akan diri dan lingkungannya, dan yang lebih penting tentu saja adalah kesadaran akan Tuhannya.

Kelima, prinsip kemaslahatan dan keutamaan. Jika ruh tauhid telah berkembang dalam sistem moral dan akhlak seseorang dengan kebersihan hati dan kepercayaan yang jauh dari kotoran maka ia akan memiliki daya juang untuk membela hal-hal yang maslahat atau berguna bagi

${ }^{22}$ Moh. Roqib, Ilmu Pendidikan Islam, Pengembangan Pendidikan Integratif di Sekolah, Keluarga dan Masyarakat, Jogjakarta: Lkis, 2009, hal. 32. 
kehidupan. Sebab, nilai tauhid hanya bisa dirasakan apabila ia telah dimanifestasikan dalam gerak langkah manusia untuk kemaslahatan dan keutamaan manusia itu sendiri.

Dengan demikian dapat disimpulkan bahwa prinsip pendidikan Islam identik dengan prinsip hidup setiap muslim, yakni beriman, bertakwa, berakhlak mulia, insan shaleh guna mengemban amanat Allah sebagai khalifah di muka bumi dan beribadat kepada Tuhan untuk mencapai ridaNya.

\section{Penanggung Jawab Pendidikan Islam}

Dalam Islam Penanggung jawab pendidikan terdapat pada lingkungan keluarga, sekolah, dan masyarakat. Masing-masing lingkungan tersebut berpengaruh terhadap pertumbuhan dan perkembangan anak.

\section{Keluarga}

Keluarga merupakan lingkungan masyarakat terkecil yang terdiri dari ayah, ibu, dan anak. Dalam lingkungan ini terletak dasar-dasar pendidikan. Disisi ini pendidikan berlangsung dengan sendirinya sesuai dengan tantangan pergaulan yang berlaku di dalamnya.

Keluarga merupakan suatu kelompok masyarakat terkecil yang terdiri atas suami-istri sebagai anggota inti, dan anak-anak kandung serta anak angkat yang pembinaannya menjadi tanggung jawabnya sebagai anggota batih. Keberadaan keluarga menjadi unsur primer bagi masyarakat yang lebih besar, sekaligus, berfungsi sebagai lembaga pendidikan dan sarana sosialisasi awal bagi anggota-anggotanya, khususnya anak. Oleh karena itu, keluarga diharapkan dapat berperan sebagai lembaga pendidikan anak atau anggota-anggota keluarga lain yang demokratis dan membebaskan sehingga menghasilkan manusia- manusia kreatif, dinamis, saleh dan arif. Manusia-manusia yang demikian diharapkan mampu menjadi anggota masyarakat yang dapat memahami dan menghormati sistem nilai dan sistem kaidah sosial, sehingga bersedia ikut berupaya mencapai tujuan hidup bersama dalam masyarakat.

Dengan demikian orang tua mempunyai tanggung jawab yang penting dalam pembentukan kepribadian anak. Karena pendidikan awal anak terletak di dalam kehidupan serta sasaran keluarga itu sendiri. Hasan Langgulung mengatakan :

Keluarga adalah unit pertama dan institusi pertama dalam masyarakat dimana hubungan-hubungan yang terdapat didalamnya, sebagian besar bersifat hubungan langsung, disitulah berkembang individu dan disitulah terbentuknya tahap-tahap awal proses pemasyarakatan (socialization), dan melalui interaksi dengannya ia memperoleh 
pengetahuan, keterampilan, minat, nilai-nilai, emosi dan sikapnya dalam hidup dan dengan itu ia memperoleh ketentraman dan ketenangan. ${ }^{23}$

Dengan demikian orang tua adalah orang yang pertama dan utama yang bertanggung jawab atas pemeliharaan dan pendidikan anak-anaknya bahkan mempunyai pengaruh yang sangat besar terhadap pertumbuhan dan perkembangannya. Keamanan dan perlindungan yang anak rasakan dalam keluarganya akan memberikan kepercayaan diri di dalam berbagai persoalan hidupnya, untuk itu orang tua harus berlaku bijaksana. Sebagaimana Al-Abdurahman Nahlawi mengatakan :

Orang tua tidak dapat memaksa anak dengan kekerasan, melainkan orang tua hendaklah dapat memahami kesukaran batin yang dialami oleh anaknya. Maka satusatunya jalan yang dapat menolong anak itu ialah menanamkan pendidikan agama di dalam diri anak. ${ }^{24}$

Jadi orang tua yang berkewajiban atas anaknya memberikan pendidikan berupa bimbingan dan binaan sehingga dapat menghasilkan pribadi anak yang baik dan mempunyai ketaatan pada orang tuanya, sebagai salah satu perhatian terhadap perhatian anaknya. Sikap saling menghargai dan membutuhkan sangat penting untuk dibina di dalam keluarga.

\section{Sekolah}

Sekolah merupakan tempat anak belajar. Fungsi sekolah tidak hanya memberikan pengajaran atau pendidikan secara formal saja tetapi juga pembentukan akhlak atau tingkah laku perlu diperhatikan. Dalam hal ini guru mempunyai peranan penting. Hasan Langgulung, ${ }^{25}$ mengemukakan sebagai berikut :

Hal paling penting yang telah dibuat oleh guru-guru yang menyebabkan perubahan kehidupan anak-anak adalah mengakui kemamapuan mereka. Anak yang tadinya selalu putus asa menjadi bersemangat menghadapi hidup dan selanjutnya diikuti oleh keberhasilan demi keberhasilan dalam hidupnya.

Seorang guru yang banyak memahami perbedaan individual murid akan lebih baik mudah mengadakan pendekatan terhadap berbagai masalah yang dihadapi muridnya. Berarti guru hendaklah memperdalam ilmunya tentang psikologi dan ilmu mendidik. Guru yang datang ke sekolah hanya karena didorong oleh gaji tanpa rasa tanggung jawab biasanya tak mau tau

${ }^{23}$ Hasan Langgulung, Asas-asas Pendidikan Islam, Jakarta, Pustaka A-Husna, 1995, hal. 346.

${ }^{24}$ Nahlawi, al-Abdurahman, Prinsif-prinsif dan Metode Pendidikan

Islam dalam Keluarga di Sekolah dan di Masyarakat, Bandung: Mizan, 1996, hal. 17.

${ }^{25}$ Hasan Langgulung, Asas-asas Pendidikan Islam, 1995,...hal. 250. 
masalah individual muridnya, sehingga takut kepadanya. Hal seperti ini tidak akan membantu murid. Sebaliknya sikap yang lebih bersahabat dengan murid adalah sikap yang terpuji.

Al-Ghazali menjelaskan tentang ciri-ciri pendidik yang boleh melaksanakan pendidikan adalah sebagai berikut :

a. Guru harus mencintai muridnya seperti mencintai anak kandungnya.

b. Guru jangan mengharapkan materi sebagai tujuan utama dari pekerjaannya, karena mengajar adalah tugas yang diwariskan oleh Nabi. Sedangkan upahnya adalah terletak pada terbentuknya anak didik yang mengamalkan ilmu yang diajarkannya.

c. Guru harus mengingatkan muridnya agar tujuannya dalam menuntut ilmu bukan hanya kebanggaan diri, tetapi untuk mendekatkan diri kepada Allah.

d. Guru mendorong muridnya agar mencari ilmu yang bermanfaat, yaitu ilmu yang membawa kebahagiaan di dunia dan di akhirat.

e. Di hadapan muridnya guru harus memberikan contoh yang baik.

f. Guru harus mengajarkan pelajaran yang sesuai dengan tingkat intelektualnya dan daya tangkap anak didiknya.

g. Guru harus mengamalkan yang diajarkannya.

h. Guru harus memahami minat, bakat, dan jiwa anak didiknya.

i. Guru harus dapat menanamkan keimanan ke dalam pribadi anak didiknya. ${ }^{26}$

\section{Masyarakat}

Manusia berbeda dengan makhluk lainnya disebabkan manusia itu tidak dapat memperbaiki kehidupannya jika ia hidup mandiri tanpa ada orang lain yang menolong memenuhi kebutuhan hidupnya.

Kebutuhan manusia yang diperlukan dari masyarakat tidak hanya yang menyangkut bidang material melainkan juga spiritual termasuk ilmu pengetahuan, pengalaman, keterampilan dan sebagainya. Dengan demikian, dapat ditarik suatu pemahaman bahwa dalam rangka memenuhi kebutuhan pendidikan manusia memerlukan adanya lingkungan sosial masyarakat. Dari sebab inilah para ahli pendidikan umumnya memasukkan lingkungan masyarakat sebagai lingkungan pendidikan.

${ }^{26}$ Muhammad Arifin, Filsafat Pendidikan Islam, Jakarta: Bina Aksara, 1998, hal. 103-104. 
Menurut Hasan Langgulung, ${ }^{27}$ untuk menjadi masyarakat model membasmi kemungkaran di atas bumi di samping beriman kepada Allah. Hal ini sebagaimana firman Allah dalam AlQur'an surat Ali Imron/3 : 104 yang berbunyi :

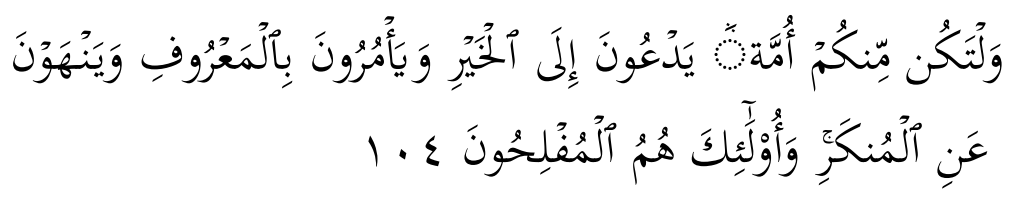

Artinya : "Dan hendaklah di antara kamu se-golongan umat yang menyeru kepada kebajikan, menyuruh kepada yang ma'ruf dan mencegah dari yang mungkar, merekalah orang-orang yang beruntung"

Karena masyarakat dalam hal ini besar pengaruhnya dalam memberikan arah terhadap pendidikan anak terutama dalam hal ini pemimpin masyarakat, tokoh masyarakat, dan penguasa yang ada di dalamnya dengan demikian mereka ikut bertanggung jawab terhadap penyelesaian pendidikan.

Bagian hasil penelitian berisi paparan hasil analisis yang berkaitan dengan pertanyaan penelitian. Pembahasan berisi pemaknaan hasil dan pembandingan dengan teori dan/atau hasil penelitian sejenis. Bagian inti atau pembahasan untuk artikel konseptual berisi paparan telaah atau pemikiran penulis yang bersifat analitis, argumentatif, logis, dan kritis. Paparan pembahasan memuat pendirian atau sikap penulis atas masalah yang dikupas. Memasukkan gambar atau tabel max 6. Jika terdapat tabel, buatlah dengan tanpa garis vertikal, judul tabel ditulis diatas tabel, garis kiri, font 12 new roman, cetak tebal dan spsasi 1, sumber ditulis dibawah tabel. Serta gambar bisa berbentuk grapik, diagram, atau photo. Bagian hasil dan pembahasan dipecah menjadi beberapa Bagian tergantung konsep pembahasan, dan ditulis dengan judul sesuai dengan topik yang dibahas.

\section{Kesimpulan}

Dari paparan di atas, bahwa pendidikan sangat memegang peran penting dalam mencerdaskan kehidupan bangsa dan dapat meningkatkan derajat manusia. Berdasarkan

${ }^{27}$ Hasan Langgulung, Asas-asas Pendidikan Islam, 1995,...h. 338. 
Heru Suparman

analisis hasil penelitian yang menggunakan metode penelitian kualitatif dan pendekatan penelitian kepustakaan (library risearch), maka dapat disimpulkan sebagai berikut:

1. Pandangan atau tinjauan Al-Qur'an tentang pendidikan Modern pada dasarnya sudah sesuai dengan ajaran Islam, khususnya Al-Qur'an yang menjadi sumber hukum Islam.

2. Pandangan Al-Qur'an tentang pendidikan Modern meliputi kritik al-Qur'an terhadap pendidikan modern, tujuan pendidikan Islam, dan penanggung jawab pendidikan Islam. Dari beberapa karakteristik tersebut, diformulasikan dengan ayat-ayat Al-Qur'an dan tafsir sebagai dalil, bahwa konsep pendidikan modern ternyata selaras dengan ajaranajaran Islam dalam mengatur tatanan hidup manusia di muka bumi ini, terutama sekali dalam konteks pendidikan.

3. Kitab suci Al-Qur'an yang diturunkan kepada Nabi Muhammad saw. merupakan landasan pokok agama Islam dalam semua sisi kehidupan umatnya. Al-Qur'an memberikan hujjah dan bukti penjelasan tentang prinsip-prinsip Islam yang menjadi inti sari dakwah. Dengan redaksi yang jelas dan akurat, memberi petunjuk kepada orang Islam tentang kekuasaan Allah, agar manusia menjadi masyarakat yang ideal di dunia. Dengan pendidikan modern diharapkan setiap individu atau kelompok bisa menerima dan menghargai setiap perbedaan, hidup berdampingan dengan damai dan tenang walaupun berbeda-beda. Sehingga terbentuk sebuah negara dan bangsa yang damai dan sejahtera. 


\section{Daftar Pustaka}

Abdurrahman, Meaningful Leaming: Re-invensi Kebenna.knaan Pembelajaran,Yogyakarta: Pustaka Pelajar, 2007.

Achmadi, Ideologi Pendidikan Islam: Paradigma Humameosentris. Yogyakarta: Pustaka Pelajar, 2008, cet. ke-2.

Achmadi, Islam sebagai Paradigma Ilmu Pendidikan. Yogyakarta: Aditya Media, 1992.

Abi Bakr al-Suyuti, Jalal al-din 'Abd. Rahman, Al-Jami'as Saagir fi Hadist al-Basyir anNazir Jilid I. Bairut: Dar al-Fikr, t.th.

Ahmad al-Zawi, al-Tahir, Tartib al-Qur'an al-Muhit "Ala Tariqah al-Misbah al-Munir wa Asas al-Balaghah Juz IV. t.tp: Dar al-fikr,t.th.

Al-Athiyah al-Abrasy, Muhammad, Al-Tarbiyah al-Islamiyah Wa Falsafatuha. Qahirah: Isa al-Babi al-Halaby, 1969.

Al-Nahlawi, Abd. Rahman, Prinsif-prinsif dan Metode Pendidikan Islam. Bandung: Diponegoro, 1996.

Arikunto, Suharsimi, Prosedur Penelitian, Jakarta : Rineka Cipta, 1996.

Arifin, Muhammad, Filsafat Pendidikan Islam. Jakarta: Bina Aksara, 1987.

Ash Shidiqie dkk, Hasbi, Al-Qur'an dan Terjemahnya, Jakarta: Intermasa, 1994.

Batubara, Muhyi, Sosiologi Pendidikan, Jakarta: Ciputat Press, 2004,

Bukhari, Muslim, ath al-Bukhari Juz I. Bairut: Dar al-Kitab al-Islam, t.th.

C. Marsh (ed),. Multicultural and Intercultural Studies, dalam Teaching Studies of Society and Environment. Sydney: Prentice-Hall, 1994

Darajat, Zakiyah, Pendidikan Islam Keluarga dan Sekolah. Jakarta: Ruhana, 1992. , Ilmu Pendidikan Islam, Jakarta: Bumi Aksara, 1991.

Departemen Pendidikan dan Kebudayaan, Kamus Besar Bahasa Indonesia, Jakarta: Balai Pustaka, 1996.

Engkoswara dan Aan Komariah, Administrasi Pendidikan, Bandung: Alfabeta, 2010

Ihsan, Fuad, Dasar-Dasar Kependidikan, Jakarta: Rineka Cipta, 2001.

Idris, Jamaluddin, Kompilasi Pemikiran Pendidikan, Yogyakarta: Taufiqiyah Sa'adah, 2005

Iskandar, Metodologi Penelitian Kualitatif, Jakarta: Gaung Persada Press, 2009.

Imran, Ali, Kebijaksanaan Pendidikan Di Indonesia, Jakarta: Bumi Aksara, 2002, 
Heru Suparman

Kartono, Kartini, Sistem Pendidikan Nasional, Jakarta: Pradnya Paramita, 2004,

Langgulung, Hasan, Beberapa Pemikirantentang Pendidikan Bandung : Al Ma'arif, 1993.

, Hasan. Asas-asas Pendidikan Islam. Jakarta: Pustaka al-

Husna Baru, 2003, cet. ke-5.

, Peralihan Paradigma dalam Pendidikan Islam dan Sains

Sosial Jakarta: Gaya Media Pratarna, 2002, cet. ke-1.

Pendidikan Islam Menghadapi Abad ke 21. Jakarta:

Pustaka al-Husna, 1988.

Marimba, Ahmad D, Pengantar Filsafat Pendidikan Islam. Bandung: Al-Ma'rif, 1964.

Mastuhu, Memberdayakan Sistem Pendidikan Islam, Jakarta: Logos, 1999.

Maulana, Achmad, Kamus Ilmiah Populer, Yogyakarta: Absolut, 2008

Muhaimin dan Abd. Mujib, Pemikiran Pendidikan Islam. Bandung: Trigenda Karya, 1993.

Mudyahardjo, Redja, Filsafat Ilmu Pendidikan, suatu Pengantar, Bandung:Remaja Rosdakarya, 2001.

Mas'ud, Abdurrahman, Menggagas Format Pendidikan Nondikotomik (Humanisme Religius sebagai Paradigma Pendidikan Islam), Yogyakarta: Gama Media, 2002.

Muhaimin, Nuansa Baru Pendidikan Islam: Mengurai Benang Kusut Dunia Pendidikan, Jakarta: Raja Grafindo Persada, 2006.

, Strategi Belajar Mengajar Pendidikan Agama Islam, Surabaya:

CV. Citra Media, Cet. Ke-1, 1996

Mulkhan, Abdul Munir, Nalar Spiritual Pendidikan: Solusi Problem Filsafat Pendidikan Islam, Yogyakarta: Tiara Wacana, 2007.

, Manusia Al Qur'an: Jalan Ketiga Religiositas di Indonesia. Yogyakarta : Impulse, 2007, hal. 319.

Misrawi, Zuhairi, Madinah (Kota Suci, Piagam Madinah, dan Teladan Muhammad SAW. Jakarta: PT Kompas Media Nusantara, 2009

Nahlawi, al-Abdurahman, Prinsif-prinsif dan Metode Pendidikan Islam dalam Keluarga di Sekolah dan di Masyarakat, Bandung:Mizan, 1996.

Purwanto, Ngalim. M, Administrasi dan Supervisi Pendidikan, Bandung:PT. Remaja Rosdakarya, 2010. 
Ramayulis, Ilmu Pendidikan Islam, Jakarta: Kalam Mulia, 1993. Rahman, Afzar, Al-Qur'an Sumber Ilmu Pengetahuan. Jakarta: Rineka Cipta, 1994.

Rosyada, Dede, Paradigma Pendidikan Demokratis: Sebuah Model Pelibatan Masyarakat dalam Penyelenggaraan Pendidikan, Jakarta: Kencana, 2007.

Shihab, M. Quraish, Tafsir al-Mishbah: Pesan, Kesan, dan Keserasian alQur'an, Volume 1, Jakarta : Lentera, 2000.

Tilaar, H.A.R., Kekuasaan dan Pendidikan, (Magelang: Indonesia Tera, 2003.

UU RI Nomor 20 Tahun 2003 tentang Sistem Pendidikan Nasional. Jakarta: Cemerlang, 2003

Uhbiyati, Nur, Ilmu Pendidikan Islam I. Bandung: Pustaka Setia, 1998.

Wahid, Abdurrahman, Islamku Islam Anda Islam Kita, Jakarta: The Wahid Institute, 2006

Zaenudin dkk, Seluk Beluk Pendidikan dari al-Ghazali. Jakarta: Bumi Aksara, 1992.

Zuhri, Saefudin dan Abd. Muid N., Wajah Damai Islam, cet. ke-1. Tangerang Selatan: Yayasan Nusa Institute Indonesia, 2016

Zubaedi, Pendidikan Berbasis Masyarakat, Yogyakarta: Pustaka Pelajar, 2005 